\title{
PENGARUH SENAM DIABETES TERHADAP KADAR GULA DARAH PADA PASIEN DIABETES MELITUS TIPE II DI WILAYAH KERJA PUSKESMAS KASSI - KASSI KOTA MAKASSAR
}

\author{
Influence of diabetes gymnastics on blood sugar level In patient of type 2 diabetes mellitus At \\ kassi - kassi health center Of makassar city \\ Rahmat Hidayah, Sumira, Simunati \\ Poltekkes Kemenkes Makassar \\ Email : Rahmathidayah1994@gmail.com
}

\begin{abstract}
The International Diabetes Federation (IDF) in 2015 stated that out of 220 countries worldwide, the number of diabetes sufferers is expected to increase from 415 million people in 2015 to 642 million in 2040. Riskesdas data shows that there is an increase in Diabetes prevalence in Indonesia from $5.7 \%$ in 2007 to $6.9 \%$ or about 9.1 million in 2013. Based on data from the Health Office of Makassar, the incidence of diabetes mellitus, in 2013 to 14,604 cases and increasing in 2014 to 21,452 cases. The purpose of this study was to determine the effect of diabetes gymnastics on blood sugar levels in patients with type 2 diabetes mellitus. This study used quasi experimental design with pre test - post test one group design approach. The population of this study is all people with diabetes melitus in Kassi - Kassi Cemetery Makassar City. Sampling method using total sampling with 10 samples. The result of this research is statistic test of Paired sample t-Test. The result of blood glucose level before and after diabetic gymnastics treatment differs significantly with value ( $p=0,000$; value $<0,05)$. So it can be concluded There is a difference in average blood sugar levels between before and after gymnastics, so there is influence of diabetes mellitus on blood sugar levels in Diabetes Mellitus Type 2 patient.
\end{abstract}

Keywords: Diabetes Mellitus Type 2, Blood Sugar Level, Diabetes Gymnastics

\begin{abstract}
ABSTRAK
Internasional Diabetes Federation (IDF) pada tahun 2015 menyebutkan bahwa dari catatan 220 negara di seluruh dunia, jumlah pederita diabetes diperkirakan akan naik dari 415 juta orang di tahun 2015 menjadi 642 juta pada tahun 2040. Data Riskesdas menunjukkan bahwa terjadi peningkatan prevalensi Diabetes di Indonesia dari 5,7\% tahun 2007 menjadi 6,9\% atau sekitar sekitar 9,1 juta pada tahun 2013. Berdasarkan data Dinas Kesehatan Kota Makassar, angka kejadian penyakit diabetes mellitus, tahun 2013 menjadi 14.604 kasus dan semakin meningkat di tahun 2014 menjadi 21.452 kasus. Tujuan Penelitian ini adalah untuk mengetahui pengaruh senam diabetes terhadap kadar gula darah pada pasien diabetes mellitus tipe 2. Penelitian ini menggunakan quasi experimental design dengan pendekatan pre test - post test one group design. Populasi penelitian ini adalah seluruh penderita diabetes melitus yang ada di Puskesmas Kassi - Kassi Kota Makassar. Metode pengambilan sampel menggunakan total sampling dengan jumlah sampel sebanyak 10 orang. Hasil penelitian menggunakan uji statistik Paired sample $t$-Test diperoleh hasil kadar gula darah sebelum dan sesudah pemberian terapi senam diabetes berbeda secara signifikan dengan nilai $(p=0,000$; value $<0,05)$. Sehingga dapat
\end{abstract}


disimpulkan Ada perbedaan rata-rata kadar gula darah antara sebelum dan Sesudah Senam, Sehingga Terdapat Pengaruh Senam Diabetes Terhadap kadar gula darah pada Pasien Diabetes Melitus Tipe 2.

\section{Kata Kunci : Diabetes Melitus Tipe 2, Kadar Gula Darah, Senam Diabetes}

\section{PENDAHULUAN}

Internasional Diabetes Federation (IDF) pada tahun 2015 menyebutkan bahwa dari catatan 220 negara di seluruh dunia, jumlah pederita diabetes diperkirakan akan naik dari 415 juta orang di tahun 2015 menjadi 642 juta pada tahun 2040, angka penderita diabetes yang didapatkan di Asia tenggara adalah : Singapura 12\%, Thailand $8 \%$, Malaysia $16,6 \%$ dan Indonesia 6,2\% (IDF, 2015) dalam Tandra, (2017).

Di Indonesia, data Riskesdas menunjukkan bahwa terjadi peningkatan prevalensi Diabetes di Indonesia dari 5,7\% tahun 2007 menjadi $6,9 \%$ atau sekitar sekitar 9,1 juta pada tahun 2013 (Kemenkes, 2016).

Prevalensi diabetes dan hipertiroid di Sulawesi Selatan yang didiagnosis dokter sebesar 1,6 persen dan 0,5 persen. DM yang didiagnosis dokter atau berdasarkan gejala sebesar 3,4 persen. Prevalensi diabetes yang didiagnosis dokter tertinggi terdapat di Kabupaten Pinrang (2,8\%), Kota Makassar $(2,5 \%)$, Kabupaten Toraja Utara $(2,3 \%)$ dan Kota Palopo (2,1\%). Prevalensi diabetes yang didiagnosis dokter atau berdasarkan gejala, tertinggi di Kabupaten Tana Toraja (6,1\%), Kota Makassar (5,3\%), Kabupaten Luwu $(5,2 \%)$ dan Kabupaten Luwu Utara $(4,0 \%)$ (Syahrir dkk., 2015).

Berdasarkan data Survailans Penyakit tidak menular Bidang P2PL Dinas Kesehatan Provinsi Sulawesi Selatan tahun 2014 terdapat Diabetes Mellitus 27.470 kasus baru, 66.780 kasus lama (Syahrir dkk., 2015).

Berdasarkan data Dinas Kesehatan Kota Makassar, angka kejadian penyakit diabetes mellitus pada tahun 2011 yaitu 5700 kasus. Pada tahun 2012 angka kejadian kasus DM meningkat menjadi 14.067 kasus, tahun 2013 menjadi 14.604 kasus dan semakin meningkat di tahun 2014 menjadi 21.452 kasus (Profil Kesehatan Kota Makassar, 2015)

Dari berbagai penelitian yang telah dilakukan oleh peneliti sebelumnya salah satu penelitian yang dilakukan oleh Daulay dkk., (2015) juga terdapat pengaruh senam diabetes terhadap kadar gula darah pada penderita diabetes mellitus di Desa Botung Kec.Kotanopan Kabupaten Mandailing Natal. Dengan nilai signifikansi $95 \%$ dengan nilai $p$ value $0,00<0,05$.

Melalui pencatatan dokumentasi data di Puskesmas Kassi-Kassi Kota Makassar yang peneliti peroleh pada Januari 2018, dengan jumlah penderita diabetes mellitus tipe 2 sebanyak 10 orang. Berdasarkan latar belakang di atas penulis tertarik untuk melakukan penelitian tentang pengaruh senam diabetes terhadap kadar gula darah pada pasien diabetes mellitus tipe 2 di wilayah keraja Puskesmas Kassi - Kassi Kota Makassar.

\section{METODE PENELTIAN}

Desain, Tempat dan waktu ; penelitian ini adalah penelitian Quasi Eksperiment dengan rancangan "One group Pretest-Postest Design". Rancangan ini tidak ada kelompok pembanding (kontrol), tetapi paling tidak sudah dilakukan observasi pertama (pretest) yang memungkinkan perubahan-perubahan yang terjadi, Yang bertujuan untuk melihat pengaruh penelitian ini menggunakan satu kelompok yaitu kelompok intervensi. Teknik pengambilan sampel pada penelitian ini menggunakan teknik total Sampling yaitu suatu teknik pengambilan sampel dimana jumlah sampel sama dengan jumlah populasi. Penelitian ini dilakukan di Wilayah Kerja Puskesmas Kassi Kassi Kota Makassar, mulai pada bulan April Mei Tahun 2018. 
Populasi ; dalam penelitian ini adalah seluruh pasien Diabetes melitus tipe 2 yang berada di wilayah kerja Puskesmas Kassi Kassi yaitu sebanyak 10 org.

Alat ukur ; yang digunakan untuk mengetahui senam diabetes yaitu dengan pengamatan (observasi). Alat pengukuran glukosa darah yaitu glukometer, untuk mendapatkan sampel darah yang akan diperiksa gula darahnya, dilakukan penusukan pada ibu jari tangan

Hasil penelitian

Analisis uniariabel

Tabel 4.1

Distribusi Frekuensi Responden Berdasarkan Usia, Jenis Kelamin, Pendidikan dan Pekerjaan di Wilayah Kerja Puskesmas Kassi - Kassi Kota Makassar, Juli 2018 $(n=10)$

\begin{tabular}{|l|c|c|}
\hline \multicolumn{1}{|c|}{ Variabel } & f & $\%$ \\
\hline Jenis Kelamin & & \\
\hline Laki - Laki & 3 & 30 \\
\hline Perempuan & 7 & 70 \\
\hline & & \\
\hline Usia & & \\
\hline $43-48$ tahun & 1 & 10 \\
\hline $49-54$ tahun & 1 & 10 \\
\hline $55-60$ tahun & 2 & 20 \\
\hline
\end{tabular}

Tabel 4.2

Distribusi Frekuensi dan Persentase Berdasarkan Kadar Gula Darah Sebelum dan Sesudah Intervensi

Pada Pasien Diabetes Melitus Tipe II di Wilayah Kerja Puskesmas Kassi - Kassi

\begin{tabular}{|c|c|c|c|c|c|c|}
\hline Variabel & $\mathrm{n}$ & Mean & SD & Min & Maks & $95 \% \mathrm{Cl}$ \\
\hline $\begin{array}{l}\text { Kadar Gula Da } \\
\text { (mg/dl) }\end{array}$ & & & & & & \\
\hline $\begin{array}{l}\text { Minggu } 1 \text { (pre } \\
\text { senam) }\end{array}$ & 10 & 265 & 48,890 & 187 & 238 & $230,03-299,97$ \\
\hline
\end{tabular}




\begin{tabular}{|c|c|c|c|c|c|c|}
\hline $\begin{array}{l}\text { Kadar Gula Darah } \\
\text { (mg/dl) }\end{array}$ & & & & & & \\
\hline $\begin{array}{l}\text { Minggu } 3 \text { (post } \\
\text { senam) }\end{array}$ & 10 & 204,5 & 26,328 & 170 & 248 & $185,67-223,33$ \\
\hline
\end{tabular}

Hasil uji Normalitas Data Kadar Gula Darah

Berdasarkan pada data tabel 4.2 diketahui rata-rata kadar gula darah minggu pertama sebelum intervensi senam adalah $265 \mathrm{mg} / \mathrm{dl}$ $(S D=48,890)$ dengan kadar gula darah terendah adalah $187 \mathrm{mg} / \mathrm{dl}$ dan kadar gula darah tertinggi adalah $238 \mathrm{mg} / \mathrm{dl}$.

Dari hasil estimasi interval dapat disimpulkan bahwa 95\% diyakini rata-rata kadar gula darah antara $230.03-299.97 \mathrm{mg} / \mathrm{dl}$. Pada minggu ketiga sesudah intervensi terjadi penurunan rata-rata kadar gula darah menjadi $204,5 \mathrm{mg} / \mathrm{dl}(\mathrm{SD}=26,328)$ dengan kadar gula darah terendah adalah $170 \mathrm{mg} / \mathrm{dl}$ dan kadar gula darah tertinggi adalah $248 \mathrm{mg} / \mathrm{dl}$. Dari hasil estimasi interval dapat disimpulkan bahwa 95\% diyakini rata-rata kadar gula darah antara 185.67 - $223.33 \mathrm{mg} / \mathrm{dl}$.

\section{Analisis Bivaribel}

Analisis bivariat digunakan dengan melihat pengaruh senam diabetes terhadap perubahan kadar gula darah. Uji bivariat data mengunakan uji Paired t- test dengan nilai < 0,05 .
Sebelum dan Sesudah Intervensi Pada Pasien

Diabetes Melitus Tipe 2 di Wilayah Kerja

Puskesmas Kassi - Kassi

\begin{tabular}{lll}
\hline Kadar Gula & \multicolumn{2}{l}{ Shapiro-wilk } \\
\cline { 2 - 3 } Darah & Statistic & Sig. \\
$\begin{array}{l}\text { Minggu 1 } \\
\text { (pre senam) }\end{array}$ & 0,944 & 0,596 \\
$\begin{array}{l}\text { Minggu 3 } \\
\text { (post }\end{array}$ & 0,923 & 0,328 \\
senam) & & \\
\hline
\end{tabular}

Berdasarkan tabel 4.3 terlihat tingkat signifikansi (sig.) atau nilai probabilitas kadar gula darah sebelum intervensi berada diatas 0,05 yaitu $(0,596>0,05)$ dan tingkat signifikansi sesudah intervensi berada diatas 0,05 yaitu $(0,328>0,05)$ Maka dapat disimpulkan bahwa data berdistribusi normal. Sehingga uji statistik yang digunakan untuk data berdistribusi normal adalah Uji Paired Sample t test.

Tabel 4.3

Tabel 4.4

Hasil Analisis Perbedaan Kadar Gula Darah Sebelum dan Sesudah Intervensi Pada Pasien Diabetes Melitus Tipe 2 di Wilayah Kerja Puskesmas Kassi - Kassi

\begin{tabular}{llrcc}
\hline \multicolumn{1}{c}{ Variabel } & $\mathbf{n}$ & mean & SD & p value \\
\hline KGD minggu 1 (pre senam) mg/dl & 10 & 265 & 48,890 & \multirow{2}{*}{0,000} \\
KGD minggu 3 (post senam) mg/dl & 10 & 204,5 & 26,328 & \\
\hline *
\end{tabular}

*uji paired sample t test

Berdasarkan pada data tabel 4.4 diketahui rata-rata kadar gula darah sebelum intervensi adalah $265 \mathrm{mg} / \mathrm{dl}$ dengan standar deviasi $48.890 \mathrm{mg} / \mathrm{dl}$. Setelah dilakukan intervensi yaitu senam diabetes didapatkan rata-rata kadar gula darah sebesar 204,5 mg/dl dengan standar deviasi $26.328 \mathrm{mg} / \mathrm{dl}$. Hasil uji statistik lebih lanjut diperoleh nilai $p$ value adalah 0,000 $<0,05(p<0,05)$.

\section{PEMBAHASAN \\ Analisis Univaribel}


Kadar Gula Darah Sebelum Melakukan Senam Diabetes di Wilayah Kerja Puskesmas Kassi - kassi.

Berdasarkan hasil distribusi frekuensi terbanyak responden dalam penelitian ini adalah berjenis kelamin perempuan dengan kategori usia terbanyak antara 61 - 66 tahun yakni 6 orang $(60 \%)$ berdasarkan tingkat pendidikan mayoritas responden berpendidikan SMA dengan profesi terbanyak sebagai IRT (Ibu Rumah Tangga). Sedangkan data hasil distribusi responden berdasarkan variabel kadar gula darah sebelum intervensi senam diabetes rata-rata $265 \mathrm{mg} / \mathrm{dl}$.

Menurut Soegondo (2011) dalam Nuari (2017) Diagnosis diabetes melitus dapat ditegakkan jika ditemukan pemeriksaan glukosa plasma sewaktu > $200 \mathrm{mg} / \mathrm{dl}$. Menurut Bilous dan Donelly, (2014) Diabetes Melitus merupakan kondisi kronis yang ditandai dengan peningkatan konsentrasi glukosa darah disertai munculnya gejala utama yang khas, yakni urine yang berasa manis dalam jumlah yang besar. Diabetes mellitus (DM) merupakan penyakit metabolic yang ditandai dengan kondisi hyperglikemia sebagai akibat dari adanya gangguan sekresi insulin, kerja insulin atau keduanya (Dian \& Achmad, 2015).

Diabetes Mellitus (DM) adalah keadaan hiperglikemi kronik disertai berbagai kelainan metabolic akibat gangguan hormonal yang menimbulkan berbagai komplikasi kronik pada mata,ginjal,saraf, dan pembuluh darah(Maghfuri, 2016).

Menurut asumsi peneliti, ketika seseorang menderita Diabetes mellitus yaitu penyakit kronik yang ditandai dengan peningkatan kadar gula darah dapat menyebabkan berbagai gangguan metabolik dan pankreas orang tersebut tidak dapat menghasilkan cukup insulin atau tidak memanfaatkan insulin sesuai semestinya untuk menyerap gula yang diperoleh dari makanan. Hal ini lah yang menyebabkan kadar gula darah menjadi tinggi akibat dari timbunan gula dari makanan yang tidak dapat diserap dengan baik. Rata-rata kadar gula darah responden sebelum dilakukan senam diabetes adalah $265 \mathrm{mg} / \mathrm{dl}$.
Tingginya kadar gula darah pada penderita diabetes dapat menyebabkan berbagai gangguan metabolik tubuh, sehingga hal ini harus mendapatkan penanganan yang tepat dan efisien.

Kadar Gula Darah Setelah Melakukan Senam Diabetes di Wilayah Kerja Puskesmas Kassi - kassi.

Berdasarkan hasil penelitian, dapat diketahui bahwa nilai median kadar glukosa darah terhadap 10 responden sebelum senam diabetes adalah $272 \mathrm{mg} / \mathrm{dl}$ dengan nilai kadar glukosa darah terendah $187 \mathrm{mg} / \mathrm{dl}$ dan kadar glukosa darah tertinggi adalah $328 \mathrm{mg} / \mathrm{dl}$. Sedangkan nilai median setelah senam diabetes adalah 199,5 mg/dl dengan nilai kadar glukosa darah terendah $170 \mathrm{mg} / \mathrm{dl}$ dan kadar glukosa darah tertinggi adalah 248 $\mathrm{mg} / \mathrm{dl}$. Hal ini berarti terdapat penurunan kadar gula darah pada penderita DM setelah dilakukan senam diabetes.

Menurut Smeltzer dan Bare (2013) latihan jasmani sangat penting dalam penatalaksanaan diabetes karena efeknya dapat menurunkan kadar glukosa darah dan mengurangi faktor resiko kardiovaskuler. Latihan akan menurunkan kadar glukosa darah dengan meningkatkan pengambilan glukosa oleh otot dan memperbaiki pemakaian insulin. Sirkulasi darah dan tonus otot juga diperbaiki dengan berolahraga.

Senam diabetes adalah senam fisik yang dirancang menurut usia dan status fisik dan merupakan bagian dari pengobatan diabetes mellitus (Persedia,2000) dalam (Nuari,2017). Menurut (Santoso,2006) dalam (Damayanti,2015) Senam diabetes adalah senam aerobic low impact dan ritmis dengan gerakan yang menyenangkan, tidak membosankan dan dapat diikuti semua kelompok umur sehingga menarik antusiasme kelompok dalam klub-klub diabetes.

Menurut asumsi peneliti, terhadap penurunan kadar gula darah pada penderita DM setelah dilakukan senam diabetes. Didapatkan Penurunan kadar gula darah ini terjadi karena senam diabetes yang dilakukan secara benar dan teratur, karena aktivitas 
sedang yang dilakukan mempunyai hubungan yang bermakna terhadap gangguan ekstremitas dimana aktivitas fisik yang rendah, salah satunya tidak teratur berolahraga berisiko untuk terjadinya gangguan gerak.

\section{Analisis Bivaribel}

Pengaruh Sebelum Senam dan Sesudah Senam Diabetes Terhadap Kadar Gula Darah.

Diketahui rata-rata kadar gula darah sebelum diberikan senam diabetes lebih besar dari pada rata-rata kadar gula darah sesudah diberikan senam diabetes yakni $265 \mathrm{mg} / \mathrm{dl}>$ $204,5 \mathrm{mg} / \mathrm{dl})$. Dapat disimpulkan terdapat penurunan kadar gula darah sesudah diberikan intervensi senam diabetes.

Penurunan rata-rata kadar gula darah ini disebabkan akibat dari senam diabetes. Latihan ini akan menurunkan kadar glukosa darah dengan meningkatkan pengambilan glukosa oleh otot dan memperbaiki pemakaian insulin. Sirkulasi darah dan tonus otot juga diperbaiki dengan berolahraga. Latihan dengan cara melawan tahanan (resistance training) I dapat meningkatkan lean body mass dan dengan demikian menambah laju metabolisme istirahat (resting metabolic rate). Semua efek ini sangat bermanfaat bagi diabetesi karena dapat menurunkan berat badan, mengurasi rasa stres dan mempertahankan kesegaran tubuh. Latihan juga akan mengubah kadar lemak darah yaitu meningkatkan kadar HDL-kolesterol dan menurunkan kadar kolesterol total serta trigliserida. Semua manfaat ini sangat penting bagi penyandang diabetes mengingat adanya peningkatan resiko untuk terkena penyakit kardiovaskuler pada diabetesi.

Manfaat olahraga bagi diabetesi antara lain meningkatkan penurunan kadar glukosa darah, mencegah kegemukan, ikut berperan dalam mengatasi kemungkinan terjadinya komplikasi aterogenik, gangguan lipid darah, peningkatan tekanan darah, hiperkoagulasi darah (Soegondo dkk. 2015).

Hasil uji statistik lebih lanjut diperoleh adanya pengaruh yang bermakna antara kadar gula darah sebelum dan sesudah pemberian senam diabetes ( $p$ value $=0,000$ ), hasil penelitian ini sejalan dengan beberapa penelitain sebelumnya yang mengungkapkan bahwa ada pengaruh yang signifikan.

Hasil ini sesuai dengan penelitian yang dilakukan Daulay, N., Dkk. (2015), tentang Pengaruh Senam Diabetes Terhadap Penurunan Kadar Gula Darah Pada Pasien Diabetes Mellitus Di Desa Botung Kecamatan Kotanopan Kabupaten Mandailing Natal, dari hasil uji didapatkan bahwa ada pengaruh yang signifikan atas pemberian senam terhadap penurunan kadar gula darah pada pasien diabetes mellitus dengan nilai $p$ value $=0,000$ $(p<0,05)$. Begitu juga dengan hasil studi yang dilakukan Zai, J. M. (2015), tentang Pengaruh Latihan Fisik Aerobik Terhadap Perubahan Kadar Glukosa Darah Pada Diabetisi Tipe II di Klub Senam Diabetes Melitus. Dari hasil analisis statistik diketahui bahwa ada pengaruh yang signifikan atas pemberian senam terhadap penurunan kadar gula darah pada pasien DM tipe II dengan nilai $p$ value $=$ $0,001(p<0,05)$.

Hasil penelitian lain yang dilakukan oleh Salindeho, A., Mulyadi, \& Rottie, J. (2016) tentang pengaruh senam diabetes melitus terhadap kadar gula darah penderita diabetes melitus tipe 2 di sanggar senam persadia. Dari hasil analisis statistik diketahui bahwa ada pengaruh yang signifikan atas pemberian senam terhadap penurunan kadar gula darah pada pasien DM tipe $I I$ dengan nilai $p$ value $=$ $0,001(p<0,05)$.

Pada keadaan normal glukosa darah diatur sedemikian rupa oleh insulin yang diproduksi oleh sel beta pankreas, sehingga kadarnya didalan darah selalu dalam batas aman, baik pada keadaan puasa maupun setelah makan (Soegondo dkk. 2015).

Pada keadaan DM tubuh relatif kekurangan insulin sehingga pengaturan kadar glukosa darah menjadi kacau. Walaupun kadar glukosa darah sudah tinggi, pemecahan lemak dan protein menjadi glukosa dihati tidak dapat dihambat (karena insulin relatif kurang) sehingga kadar glukosa darah dapat semakin meningkat (Soegondo dkk. 2015). 
Glukosa Darah Di dalam darah terdapat zat glukosa, glukosa ini gunanya untuk dibakar agar mendapatkan kalori atau energi. Sebagian glukosa yang ada dalam darah adalah hasil penyerapan dari usus dan sebagian lagi dari hasil pemecahan simpanan energi dalam jaringan. Glukosa yang ada di usus bisa berasal dari glukosa yang kita makan atau bisa juga hasil pemecahan zat tepung yang dimakan dari nasi, ubi, jagung, kentang, roti atau dari yang lain (Djojodibroto, 2012) dalam (Zai, 2015).

Menurut Santoso,(2006) dalam

Damayanti,(2015) Senam diabetes adalah senam aerobic low impact dan ritmis dengan gerakan yang menyenangkan, tidak membosankan dan dapat diikuti semua kelompok umur sehingga menarik antusiasme kelompok dalam klub-klub diabetes.

Latihan jasmani sedang yang dilakukan secara teratur dapat mencegah dan menghambat timbulnya diabetes dini (American Diabetes Association, 2004) dalam (Damayanti,2015).

Menurut asumsi peneliti, dari hasil penelitian ini dapat diketahui bahwa dengan melakukan senam diabetes secara konsisten pada penderita diabetes mellitus tipe 2 mempunyai pengaruh yang sangat bermakna positif terhadap pengontrolan kadar gula darah,terlebih pada penderita diabetes yang mengalami peningkatan kadar gula dalam darah yang dapat menurunkan jumlah nilai kadar gula darah setelah melakukan senam diabetes dengan baik dan konsisten. Gerakan dinamis yang dilakukan oleh diabetisi, dengan cara mengikuti irama music yang juga dipilih sehingga melahirkan ketentuan ritmis, kontinuitas dan durasi tertentu dapat menimbulkan perubahan metabolik, tingkat kebugaran, juga menjaga keseimbangan cairan tubuh.

\section{KESIMPULAN}

Rata-rata kadar gula darah sebelum senam adalah $265 \mathrm{mg} / \mathrm{dl}$. Rata-rata kadar gula darah sesudah senam adalah $204,5 \mathrm{mg} / \mathrm{dl}$. Ada perbedaan rata-rata kadar gula darah antara sebelum dan sesudah senam, sehingga terdapat pengaruh senam diabetes terhadap kadar gula darah pada pasien diabetes melitus tipe 2 di wilayah kerja Puskesmas Kassi Kassi Kota Makassar.

\section{SARAN}

\section{Bagi Pasien Diabetes Melitus Tipe 2}

Di sarankan kepada pasien diabetes dapat mengetahui manfaat senam diabetes dan mampu melakukan senam diadetes secara mandiri untuk menjaga kadar gula darah dapat tetap stabil.

\section{Bagi Peneliti Selanjutnya}

Perlu dilakukan penelitian dengan jumlah sampel yang lebih banyak dan menguji variabel confounding lainnya yang berhubungan dengan senam dan kadar gula darah.

Perlu dilakukan kombinasi perlakuan senam diabetes dengan perlakuan lainnya yang secara teroritis dianggap dapat menurunkan kadar gula darah pada pasien diabetes melitus tipe 2 .

\section{Bagi Puskesmas}

Hasil penelitian dapat digunakan sebagai bahan masukan dalam penanganan pasien penderita dibetes melitus untuk menurunkan kadar gula darah dengan menggunakan senam diabetes di Puskesmas tersebut.

\section{UCAPAN TERIMA KASIH}

Ayahanda Ahmad dan Ibunda Mardia serta Kakak Nurhidayah dan Adik Nursyaadah yg selalu memberikan dorongan semangat sehingga menekan kembali semangat ketekunan, kesabaran dan doa demi kesuksesan peneliti.

Junaidi selaku Ketua Prodi Diploma IV Keperawatan Jurusan Politeknik Kesehatan Makassar.

Sumira selaku pembimbing I dan penguji yang memberikan bimbingan dan arahan selama penyusunan skripsi hingga selesai.

Simunati selaku pembimbing II dan penguji yang memberikan bimbingan dan arahan selama penyusunan skripsi hingga selesai 
Suhartatik selaku penguji yang memberikan bimbingan dan arahan selama penyusunan skripsi hingga selesai

Heriansyah selaku Pembimbing Akademik yang selama ini memberikan pengarahan mengenai perkuliahan dari awal semester hingga akhir
Teman-teman seperjuangan Mahasiswa Poltekkes Kemenkes Makassar Jurusan Keperawatan Prodi DIV Angkatan 2014 dan Teman - teman Kost yang selalu setia menjadi pendengar segala keluh kesah dan senantiasa menemani saya dalam suka dan duka.

\section{DAFTAR PUSTAKA}

Daulay, N., Dkk. (2015). Pengaruh Senam Diabetes Terhadap Penurunan Kadar Gula Darah Pada Pasien Diabetes Mellitus Di Desa Botung Kecamatan Kotanopan Kabupaten Mandailing Natal. https://ejurnal.stikesrshajimdn.ac.id/download.php?file=pengaruh\%20senam\%20diabetes jurnal.pdf (Di Akses Tanggal 24 Januari 2018)

Kemenkes. (2016, April 07). http://www.depkes.go.id/article/view/16040700002/menkes-mari-kitacegah-diabetes-dengan-cerdik.html. Retrieved Februari 05, 2018, from http://www.depkes.go.id/pdf.php?id=16040700002: http://www.depkes.go.id

Notoatmodjo, Soekidjo. (2015). Metedeologi Penelitian Kesehatan. Jakarta: Roneka Cipta

Nursalam. (2016). Metedeologi Penelitian IImu keperawatan. Jakarta: Salemba Medika

Profil Kesehatan Kota Makassar. (2015). Retrieved April 12, 2018, from https://www.google.co.id/: http://dinkeskotamakassar.com/index.php/2017-02-09-09-3056?download=17:profil-kesehatan-kota-makassar-tahun-2015

Salindeho, A., Mulyadi, \& Rottie, J. (2016). Pengaruh Senam Diabetes Melitus Terhadap Kadar Gula Darah Penderita Diabetes Melitus Tipe 2 Di Sanggar Senam Persadia Kabupaten Gorontalo. ejournal keperawatan volume 4 nomor 1 . https://ejournal.unsrat.ac.id/index.php/jkp/article/viewFile/10856/10445 (Di Akses Tanggal 24 Januari 2018)

Syahrir, Dkk. (2015). Profil Kesehatan Sulawesi Selatan 2014. Makassar: Dinas Kesehatan Provinsi Sulawesi Selatan .

http://www.depkes.go.id/resources/download/profil/PROFIL_KES_PROVINSI_2014/27_S ulawesi_Selatan_2014.pdf (Di Akses Tanggal 6 Februari 2018)

Daulay, N., Dkk. (2015). Pengaruh Senam Diabetes Terhadap Penurunan Kadar Gula Darah Pada Pasien Diabetes Mellitus Di Desa Botung Kecamatan Kotanopan Kabupaten Mandailing Natal.

https://ejurnal.stikesrshajimdn.ac.id/download.php?file=pengaruh\%20senam\%20diabetes jurnal.pdf (Di Akses Tanggal 24 Januari 2018)

Fady, AF. (2015). Madu dan Luka Diabetik Metode Perawatan Luka Komplementer. Yogyakarta: Gosyen Publishing 
Handayani, D., \& Rudijianto, A. (2015). Penatalaksanaan Gizi Pada Diabetes Mellitus. Malang: Damar Wijaya.

Kemenkes. (2016, April 07). http://www.depkes.go.id/article/view/16040700002/menkes-mari-kitacegah-diabetes-dengan-cerdik.html. Retrieved Februari 05, 2018, from http://www.depkes.go.id/pdf.php?id=16040700002: http://www.depkes.go.id

LeMone, Priscilla, dkk. (2015). Buku Ajar Keperawatan Medikal Bedah. Jakarta: EGC

Maghfuri, Ali. (2016). Buku Pintar Perawatan Luka Diabetes Melitus. Jakarta: Salemba Medika

Notoatmodjo, Soekidjo. (2015). Metedeologi Penelitian Kesehatan. Jakarta: Roneka Cipta

Nuari, N. A. (2017). Strategi Manajemen Edukasi Pasien Diabetes Mellitus. Yogyakarta: Deepublish.

Nursalam. (2016). Metedeologi Penelitian IImu keperawatan. Jakarta: Salemba Medika

Profil Kesehatan Kota Makassar. (2015). Retrieved April 12, 2018, from https://www.google.co.id/: http://dinkeskotamakassar.com/index.php/2017-02-09-09-3056?download=17:profil-kesehatan-kota-makassar-tahun-2015

Rumahorbo, Hotma. (2014). Mencegah Diabetes Melitus dengan Perubahan Gaya Hidup. Bogor: In Media

Salindeho, A., Mulyadi, \& Rottie, J. (2016). Pengaruh Senam Diabetes Melitus Terhadap Kadar Gula Darah Penderita Diabetes Melitus Tipe 2 Di Sanggar Senam Persadia Kabupaten Gorontalo. ejournal keperawatan volume 4 nomor 1 . https://ejournal.unsrat.ac.id/index.php/jkp/article/viewFile/10856/10445 (Di Akses Tanggal 24 Januari 2018)

Smeltzer, Susanne dan Bare, Brenda. (2013). Buku Ajar Keperawatan Medikal Bedah. Jakarta: EGC

Soegondo, S., Soewondo, P., \& Subekti, I. (2015). Penatalaksanaan Diabetes Mellitus Terpadu. Jakarta: Badan Penerbit FKUI.

Suyono, S., Dkk. (2015). Penatalaksanaan Diabetes Melitus Terpadu. Jakarta: Balai Penerbit FKUI.

Syahrir, Dkk. (2015). Profil Kesehatan Sulawesi Selatan 2014. Makassar: Dinas Kesehatan Provinsi Sulawesi Selatan .

http://www.depkes.go.id/resources/download/profil/PROFIL_KES_PROVINSI_2014/27_S ulawesi_Selatan_2014.pdf (Di Akses Tanggal 6 Februari 2018)

Tandra, H. (2017). Segala sesuatu yang harus Anda ketahui tentang DIABETES. Jakarta: PT Gramedia. 
Tarwoto, dkk. (2016). Keperawatan Medikal Bedah Gangguan Sistem Endokrin. Jakarta Timur: CV Trans Info Media

Wijaya, SA dan Putri, MY. (2013). KMB2 Keperawatan Medikal Bedah (Keperawatan Dewasa). Yogyakarta: Nuha Medika

Zai, J. M. (2015). Pengaruh Latihan Fisik Aerobik Terhadap Perubahan Kadar Glukosa Darah Pada Diabetisi Tipe II di Klub Senam Diabetes Melitus Di Wilayah Kerja Puskesmas Helvetia Medan. http://103.15.241.30/opac/uploaded_files/dokumen_isi/Monograf/1102176_001.pdf (Di Akses Dari Tanggal 07 Februari 2018) 